\title{
Hyper-lgD syndrome: a new mutation (p.R277G) with a severe phenotype
}

\author{
J Santos ${ }^{1 *}$, Jl Arostéguii ${ }^{2}$, MJ Brito ${ }^{3}$, C Neves $^{3}$, M Conde $^{4}$ \\ From 18th Pediatric Rheumatology European Society (PReS) Congress \\ Bruges, Belgium. 14-18 September 2011
}

\section{Background}

Hyperimmunoglobulin D Syndrome (HIDS is a rare autosomal recessive condition caused by mutations in the Mevalonate Kinase (MVK) gene that codes for MVK, an essential enzyme in the isoprenoid pathway. It shows a wide phenotypic spectrum probably related with the residual activity of this enzyme $(1-20 \%$ of normal). So far, about 63 mutations have been described and the four most prevalent mutations account for more than $70 \%$.

\section{Aim}

Case report of a new mutation of the MVK gene in a child with a severe Hyper-IgD syndrome.

\section{Results}

A 2-year-old portuguese boy presented with recurrent episodes of fever and malaise, cervical lymphadenopathy and hepatosplenomegaly since 12 months of age. Rash was seen once. During acute attacks laboratory evaluation demonstrated microcytic hypochromic anemia $(\mathrm{Hg}$ 8-10 g/dl), leukocytosis with neutrophilia (WBC 23 490$32280 / \mathrm{mm}^{3}$ ) and increased ESR (61-91 $\left.\mathrm{mm} / \mathrm{h}\right)$, CRP $(6.27-18.49 \mathrm{mg} / \mathrm{dl})$ and serum amyloid A (104-510 mg/ L). Clinical and laboratory improvement was seen between attacks. Renal and liver functions, like cardiac and ophthalmologic evaluations, were normal. Infectious causes, primary immunodeficiency, neoplastic and autoimmune diseases were excluded. Despite normal serum IgD, HIDS was clinically suspected. DNA sequence analysis revealed a homozygous Arg-277-Gly (p.R277G) new mutation in MVK gene. The healthy non-consanguineous parents were heterozygous for this mutation.

\footnotetext{
* Correspondence: Joanaasantos@gmail.com

'Pediatric Department, Hospital Dona Estefânia - CHLC - EPE, Lisbon, Portugal

Full list of author information is available at the end of the article
}

Short NSAIDs and corticosteroid courses were given during attacks with poor benefits. Anakinra was started $(2 \mathrm{mg} / \mathrm{Kg} /$ day), with partial clinical response.

\section{Discussion}

R277G is a previously unreported MVK mutation and in this case was associated with a severe phenotype. Further studies are needed to evaluate a co-relation genotype-enzyme activity-phenotype and by so helping to define best therapeutic strategies for each patient.

\section{Author details}

'Pediatric Department, Hospital Dona Estefânia - CHLC - EPE, Lisbon, Portugal. ${ }^{2}$ Unidad de Enfermedades Autoinflamatorias, Hospital Clínic, Barcelona, Spain. ${ }^{3}$ Pediatric Infectious Diseases Unit, Hospital Dona Estefânia - CHLC - EPE, Lisbon, Portugal. ${ }^{4}$ Pediatric Rheumatology, Hospital Dona Estefânia - CHLC - EPE, Lisbon, Portugal.

Published: 14 September 2011

doi:10.1186/1546-0096-9-S1-P21

Cite this article as: Santos et al:: Hyper-lgD syndrome: a new mutation (p.R277G) with a severe phenotype. Pediatric Rheumatology 2011 9(Suppl 1):P21.

Submit your next manuscript to BioMed Central and take full advantage of:

- Convenient online submission

- Thorough peer review

- No space constraints or color figure charges

- Immediate publication on acceptance

- Inclusion in PubMed, CAS, Scopus and Google Scholar

- Research which is freely available for redistribution
C Biomed Central

(c) 2011 Santos et al; licensee BioMed Central Ltd. This is an open access article distributed under the terms of the Creative Commons Attribution License (http://creativecommons.org/licenses/by/2.0), which permits unrestricted use, distribution, and reproduction in any medium, provided the original work is properly cited. 